\title{
Refined Classification of Personnel Costs with the Allocation of an Additional Classification Feature
}

\author{
Natalia Kuritsyna*, Ekaterina Ksenofontova, and Lidia Antipova \\ Saint Petersburg State University of Economics, 191023 Saint Petersburg, Russia
}

\begin{abstract}
This article is devoted to the analysis of approaches to the classification of personnel costs. Based on the analyzed material, a conclusion has been made about different approaches to accounting for personnel costs, as well as their incomplete classification. The authors attempted to create a refined classification of personnel costs with the allocation of an additional classification feature based on the theory of personnel logistics.
\end{abstract}

\section{Introduction}

An integral part of the personnel policy of any organization is to determine the costs of acquiring and using a qualified workforce. According to the modern theoretical foundations of personnel management, personnel costs represent an investment in the company's profit in the future, while emphasizing the importance of personnel to the organization.

Today there are many theories and approaches to the classification of personnel costs. The classical approach allows the total personnel costs to be presented as the sum of direct and indirect costs. At the same time, direct costs can be attributed to a specific cost object (product, service). For example, the salary of a programmer in an organization engaged in the production and sale of software. Indirect costs cannot be attributed to a specific cost object, they are associated with the maintenance of the organization as a whole.

The standard classification of the cost of labor is recommended by the International Conference of Labor Statisticians [13] and identifies 10 main cost items: direct payments for wages and salaries; monetary compensation for non-worked time; bonuses and other motivational monetary awards; the cost of housing, fuel, and other employee benefits; social security and employee protection costs; training costs; consumer services costs; taxes; additional costs of the organization for work clothes, organization of transport, provision of medical services, etc.

The classical theory of cost classification divides the cost of personnel (labor) into direct costs associated with payment of hours worked or the amount of work performed and indirect costs, which are due to the need to reimburse additional costs.

\footnotetext{
* Corresponding author: kuritsyna@bk.ru
} 
In Russia, according to the current instruction of the State Statistics Committee of the Russian Federation dated 07.19.1995 [14], the organization's personnel costs are divided into three groups: the payroll, social payments, and other expenses.

When the balance sheet determination of personnel costs take into account the total amount of expenses of the organization for personnel, consisting of: time and piecework wages; bonus payments; the cost of social benefits; costs of providing workers with overalls, equipment of premises, etc.; contributions to state and social insurance funds; taxes. All of the above classifications have a narrow approach to costs. With the development of information technology, with the advent of new methods of personnel management, approaches to the distribution of organizations' costs for personnel are actively changing.

\section{Modern approaches to the distribution of organizational costs for personnel}

There are many new approaches to allocating an organization's personnel costs. Questions about personnel costs are discussed in detail by many domestic and foreign authors [1-9]. When determining the structure of personnel costs, all authors take into account such groups as: costs associated with wages of employees, deductions to social and other funds, and other costs.

Potemkin V.K. in his work [2] classifies costs on six grounds: phases of the reproduction process, the value of the organization, purpose, sources of funding, nature of costs, place of origin. This classification expands the cost structure, makes it possible to consider personnel costs depending on the structural unit in which the costs arise, analyze various sources of financing personnel costs, assess the value for the organization in certain costs, which in turn can serve as a source of definition of the item cost savings for the organization.

At the same time, the author departs from this classification and adheres to the classical theory of including costs in the cost of products (works, services) of the organization. The author carries out the inclusion of personnel costs in the prime cost on the basis of the "Regulation on the composition of costs for the production and sale of products" [10] (hereinafter referred to as the Regulation), without taking into account his classification. The main components of the personnel cost item according to the Regulation are shown in Figure 1.

To the costs not included in the prime cost, the author includes the costs of training, carrying out various activities for employees, the maintenance of classrooms and institutions, bonuses from special and targeted funds, material assistance, compensation payments, payment of vacation packages and treatment.

The cost structure, considered from the angle of personnel logistics, gets a completely different form. Personnel logistics has given a new round in the development of the theoretical foundations of personnel management in the organization, and has made it possible to improve the structure of personnel costs through the use of a deeper analysis of items of personnel costs. Personnel logistics allows you to explore and optimize personnel flows in an organization through the effective use and distribution of personnel costs.

Modern management theory considers the organization's personnel as a resource that is constantly changing due to personnel movement and has the characteristics of a human resource.

The peculiarity of human resources is that they are not the property of the enterprise, it is a temporary labor force that has entered into an employment contract with the organization. 
Personnel costs included in the cost of production

basic salary; this category includes salaries and hourly wage payments.

variable wages; this category includes payments to the

pieceworkers, commissions, accord wages

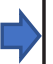

all types of bonuses, including bonuses for the year, quarter, month, one-time bonuses for completing certain tasks;

$\Rightarrow \sqrt{\text { surcharges and allowances to wages (surcharges for overtime work, on weekends and }}$ holidavs. shift allowances. non-production bonuses):

payment for non-worked time (annual vacations, holidays, time of illness)

contributions to the fund of insurance benefits (life insurance, sickness and accident insurance), contributions to social insurance funds established by law, i.e. government social security systems, federal unemployment insurance, workers' compensation, temporary disability insurance, etc.

the cost of social benefits, health care costs, free meals, provision of free services, contributions to the old-age pension fund, etc.

recruitment, replenishment and training costs; expenses for work with personnel (for example, costs of information systems, factory newspaper, service of complaints and suggestions: costs of maintaining the personnel department. etc.):

other payments (severance pay, additional assistance to the unemployed, etc.).

Fig. 1. Costs included in the prime cost of goods (works, services) [10].

HR logistics has a certain structure, consisting of such elements as [11]:

- input streams and their optimization, namely: analysis of personnel composition, planning of personnel movement, recruitment of personnel, adaptation;

- internal flows and their optimization;

- outgoing flows and their optimization, namely: release of personnel (dismissal);

- analysis of the organization's staffing.

Human resource logistics contributes to the effective management of the organization through the introduction of a planned and systematic process for the formation of highly qualified personnel potential, which is associated with the entire chain of personnel management technologies.

In the scientific works of domestic and foreign authors, the object of research is rarely the staff flow. One of the few examples where the object of research is the staff flow is the work of N.G. Kormin "The use of HR logistics in personnel management" [12]. The main direction of the development of the theory of personnel costs is the inclusion of methods of personnel logistics in combination with generally accepted methods of personnel management. With this approach, the distribution of personnel costs is carried out within 
the framework of the organization's personnel flow. The organization's personnel flow system is shown in Fig. 2.

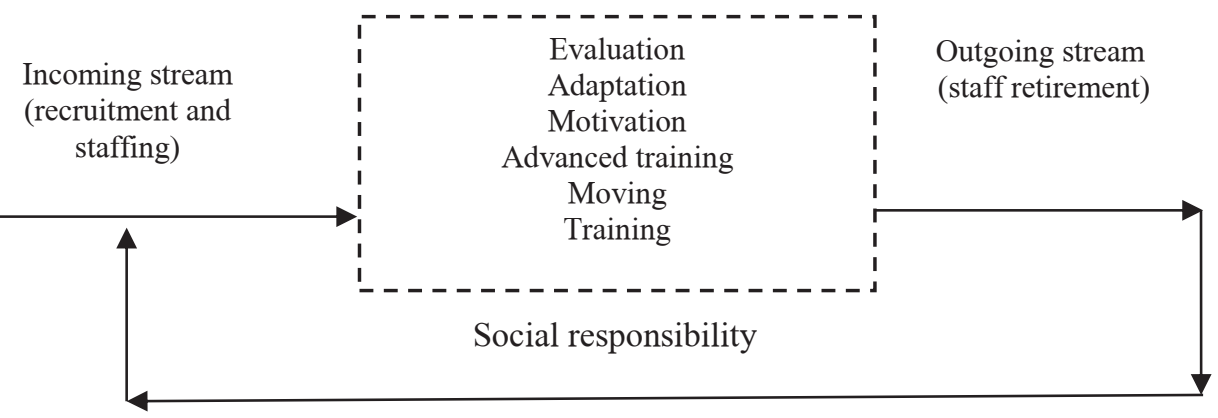

Fig. 2. The system of personnel flow movement in the organization.

The consistency of the personnel flow is ensured by the interconnection of the incoming flow (selection and recruitment of personnel), outgoing flow (retired personnel) and feedback. Due to this, personnel are renewed, that is, the replacement of retired specialists with the new ones. The formation of personnel flows is based on the process of reproduction of the labor force, which consists in restoring and maintaining the ability to perform labor functions of existing workers, as well as attracting new workers due to natural population growth.

The key factor influencing the reproduction of the labor force is the system of general education and vocational training of personnel with subsequent additional vocational education.

The movement of personnel flows in an organization presupposes the process of updating the workforce by retiring part of its employees and replacing them with new specialists. Stable reproduction of personnel requires a high level of costs of the organization for personnel.

\section{Classification of personnel costs with the allocation of an additional classification feature}

The authors' proposal is to supplement the classification of costs (Table 2) for personnel with the allocation of an additional classification feature "Technology of personnel" and the distribution of costs for personnel throughout the movement of the personnel flow in the chain of personnel technologies.

Table 1. Classification of personnel costs according to "Personnel technology" classification criterion.

\begin{tabular}{|l|l|l|}
\hline No. & \multicolumn{1}{|c|}{ HR technology } & \multicolumn{1}{c|}{ Cost } \\
\hline 1 & $\begin{array}{l}\text { Recruitment and } \\
\text { staffing }\end{array}$ & $\begin{array}{l}\text {-costs for an organized search and recruitment of employees; } \\
\text { - lifting costs; } \\
\text {-payment of travel to the place of work; } \\
\end{array}$ \\
& & $\begin{array}{l}\text { - cost of staff training (briefing); } \\
\text {-payment of leave before starting work to graduates of educational } \\
\text { institutions; } \\
\text { - expenses for registration of the employee. }\end{array}$ \\
\hline 2 & Personnel assessment & $\begin{array}{l}\text {-costs for certification of personnel; } \\
\text { - costs of the assessment center; } \\
\text { - payment for the work of experts. }\end{array}$ \\
& &
\end{tabular}


Table 1. Continued

\begin{tabular}{|l|l|l|}
\hline 3 & $\begin{array}{l}\text { Adaptation } \\
\text { personnel }\end{array}$ & $\begin{array}{l}\text { - payment for mentoring; } \\
\text { - expenses for providing employees with housing. }\end{array}$ \\
\hline 4 & $\begin{array}{l}\text { Salary (employee's } \\
\text { remuneration) }\end{array}$ & $\begin{array}{l}\text {-compensation of employees; } \\
\text { - refund of payment for non-worked time; } \\
\text { - insurance contributions to the social insurance Fund; } \\
\text { - costs of social benefits; } \\
\text { - expenses for free food, medical care, provision of free services, } \\
\text { payment for rest for employees and their families, contributions to the } \\
\text { old-age pension Fund, etc.; } \\
\text { - expenses for payment of proposals for innovation and for inventions. }\end{array}$ \\
\hline 5 & Personnel motivation & $\begin{array}{l}\text { - all types of bonus payments; } \\
\text { - allowances and surcharges to the salary. }\end{array}$ \\
\hline 6 & Advanced training & $\begin{array}{l}\text { - training, professional development; } \\
\text {-retraining of personnel; } \\
\text { - payment for internships; } \\
\text { - payment of wages during on-the-job training. }\end{array}$ \\
\hline 7 & Moving within an & $\begin{array}{l}\text { - expenses for registration of the employee. } \\
\text { - cost of training the personnel reserve. }\end{array}$ \\
\hline 8 & Perganization & $\begin{array}{l}\text { - allowances for conducting the seminars, trainings, lectures, etc.; } \\
\text { - expenses for the organization of professional training (preparation and } \\
\text { equipment of premises, devices, etc.) } \\
\text { - purchase of software for staff training; } \\
\text { - handling of educational classes and institutions. }\end{array}$ \\
\hline 9 & Staff retirement & $\begin{array}{l}\text { - severance payments on termination of employment; } \\
\text { - costs of downtime of the workplace during the search for a } \\
\text { replacement; } \\
\text { - financial assistance to the unemployed. }\end{array}$ \\
\hline
\end{tabular}

Thus, we use the following formula to estimate the organization's total personnel costs:

$$
C=\sum_{i=1}^{n} 3 r+3 a s s+3 a d+3 l c e+3 m+3 t c+3 p d+3 m o v+3 s r
$$

where:

$\mathrm{Cr}$ - costs for recruitment and hiring of staff;

Cass - costs for personnel assessment;

Cad - the cost of staff adaptation;

Clce - labor costs for employees;

$\mathrm{Cm}-$ cost of staff motivation;

Ctc - training costs;

Cpd - costs for professional development;

$\mathrm{Cmov}$ - costs for moving staff within the organization;

Csr - costs of staff retirement.

Recruitment and staffing is of particular interest. In Russian practice, operational costing of hiring personnel is rarely used. Personnel costs are usually deductions from the payroll in accordance with the law.

In the current economic situation and taking into account the trends in the labor market, the costs of recruiting and staffing must include the costs of wages (with deductions) for attracting such a category of workers whose working time was associated with the recruitment and selection process. The organization can attract recruiting agencies, which also creates certain financial costs. When selecting personnel in professions requiring special testing using special equipment, it is necessary to take into account the depreciation costs of such equipment.

Depending on the goals facing the organization and the specifics of personnel policy, programs of personnel work are developed for a certain period. It is usually 3-5 years. It is extremely important to determine the list of activities and their priority in terms of the distribution of the organization's costs. It should be noted that, theoretically and practically, 
the need has long been ripe to improve methods for optimizing personnel policy. In particular, cost reduction remains an important challenge for the organization. Cost analysis according to the proposed classification will allow as follows:

1. Determine the amount of expenses of the organization for personnel at each stage of the movement of the personnel stream;

2. Identify opportunities for cost optimization (for example, switching to outsourcing, reducing the cost of staff motivation by redistributing payments, etc.).

3. Improve the regulation of the organization's personnel policy.

\section{Conclusions}

1. Analysis of the classical theory of distribution of personnel costs has shown that personnel costs (labor) are divided into direct and indirect ones. At the same time, there is no accounting for the operational costs associated with the process of personnel renewal, namely the selection and recruitment, training and retraining of personnel.

2. Analysis of modern approaches to the distribution of costs showed that the structure of personnel costs takes into account such groups as: labor costs, deductions for social needs, other costs and they can be classified according to six criteria: phases of the reproduction process, the value of the organization, purpose, sources of funding, nature of costs, place of origin. But the costs of training, carrying out various activities for employees, the maintenance of classrooms and institutions, bonuses from special and targeted funds, material assistance, compensation payments, payment of vouchers and treatment and other costs related to the reproduction of personnel are not taken into account in the cost structure.

3. Based on the approach of personnel logistics to the formation of personnel costs, which provides for a planned and systematic process of organized influence on the formation and distribution of personnel, creating conditions for the use of labor resources, as well as its all-round development, the authors have formed a system of personnel flow in the organization.

4. Supplementing the classification of personnel costs with the allocation of an additional classification feature "Personnel technology" and the distribution of personnel costs throughout the movement of the personnel flow in the personnel technology chain will contribute to cost optimization, due to the ability to determine the exact value of the organization's costs for personnel at each stage of the movement of personnel flow.

\section{References}

1. R.J. Ehrenberg, R.S. Smith, Modern Labor Economics: Theory and Public Policy, 3(5) (1996)

2. V.K. Potemkin, O.A. Popazova, Personnel audit and personnel control, 292 (2013)

3. F. Amodio, M.A. Martinez-Carrasco, Review of Economic Studies, 85(4), 1937 (2018)

4. V. Makedon, O. Hetman, L. Yemchuk, N. Paranytsia, S. Petrovska, Journal of Security and Sustainability Issues, 8(3), 345 (2019)

5. M. Santalova, D. Balahanova, S. Kuizheva, E. Lesnikova, E. Trunova Advances in Intelligent Systems and Computing, 726, 537 (2019)

6. H. Schumacher, I. Kesternich, M. Kosfeld, J. Winter, Review of Economic Studies 84(3), 1346 (2017)

7. Yu.D. Odegov, T.V. Nikonova, Audit and control of personnel, 2nd ed., 672 (2010)

8. Personnel management of the organization: textbook, 638 (2006) 
9. Fitz-Enz Yak, Return on investment in personnel: measuring the economic value of personnel (2006)

10. Regulations on the composition of costs for the production and sale of products (works, services) included in the cost of products (works, services), and on the procedure for generating financial results taken into account when taxing profits, 241(1992)

11. I.S. Golovina, Proceedings of the VIII international student electronic scientific conference" Student scientific forum ", 6, 1 (2017)

12. N. Kormin, Bulletin of the Chelyabinsk state University, Economy, 14(7(108)), 138 (2008)

13. International Standard Classification of Labor Cost, recommended by the International Conference of Labor Statisticians

14. Letter of the state tax service of the Russian Federation from 03.08.1995 N ВП-4$10 / 43 \mathrm{H}$ "on approval of the Instructions on the composition of the payroll and social payments" 